\title{
The development of small enterprises in Bulgaria, Czech Republic and the Russian Federation ${ }^{*}$
}

\author{
Eckhard Dittrich, Heiko Schrader, Christo Stojanov**
}

During the past, the evaluation of the chances of economic transformation and development of Eastern Europe was largely shaped by the view on the modernization and organizational restructuring of large enterprises/combines. Various scholars were sceptical how far these could contribute to a functioning market economy, due to their heritage from the planned economy. The authors therefore investigated how far small entrepreneurs support the transformation process to a market economy. Quantitative and qualitative research was done in Bulgaria, Czech Republic and the Russian Federation in 2003 and 2004 to provide a comprehensive image about the milieu of small enterprises and their ways of operation.

In der Vergangenheit wurden die Chancen ökonomischer Transformation und der Entwicklung Osteuropas von der Perspektive der Modernisierung und organisationale Umstrukturierung der Großunternehmen/Kombinate betrachtet. Es herrschte Skepsis, ob sie mit ihrem Erbe der Planwirtschaft zu einer funktionierenden Marktwirtschaft beitragen könnten. Deshalb untersuchten die Autoren, inwieweit Kleinunternehmer den Transformationsprozess zur Marktwirtschaft unterstützen. In den Jahren 2003 und 2004 führten die Autoren quantitative und qualitative Forschung in Bulgarien, Tschechien und der Russischen Föderation durch, um ein möglichst umfassendes Bild zu erhalten über das Milieu von Kleinunternehmen und ihre Art zu operieren.

Keywords: transformation, small entrepreneurs, networks, Russia, Czech Republic, Bulgaria

Manuscript received: 18.04.08, accepted: 21.04 .08 (0 revision)

** Eckhard Dittrich, Prof. Dr., Institute for Sociology, Otto-von-Guericke-Universität, Magdeburg, Deutschland. Main research areas: Economic sociology and transformation of Eastern Europe.

Heiko Schrader, Prof. Dr., Institute for Sociology, Otto-von Guericke-Universität, Magdeburg, Deutschland. Main research areas: Economic sociology and transformation of Eastern Europe. Corresponding address: heiko.schrader@ocgu.de.

Christo Stojanov, Dr., Institute for Sociology, Otto-von-Guericke-Universität, Magdeburg, Deutschland. Main research areas: Economic sociology and transformation of Eastern Europe. 


\section{Researched topic}

In this article the results of a research project on small enterprises in Bulgaria, the Czech Republic and the Russian Federation ${ }^{1}$ will be discussed. During the years 2003 and 2004 we collected quantitative and qualitative data. ${ }^{2}$ The 180 questionnaires per country provided a general data basis with regard to questions of the foundation and growth of small enterprises and their economic environment. With the additional 30 qualitative interviews per country we deepened knowledge on the conducts of life (Lebensführung) in the social milieu of small enterpreneurs ${ }^{3}$ and investigated their role in the transformation process to get a comprehensive image of small enterprises in post-socialist contexts and transformation processes.

Due to the specific historical preconditions we believe that the dynamics on the historical path of economic modernization in Western Europe cannot be assumed to happen automatically but with retardation in Eastern and MiddleEurope (the catching-up modernization argument). Already quite soon after the implosion of the Eastern bloc, Stark (1994) and Staniszkis (1991b) put forward strong arguments against a transformation concept which considered abrupt change occurring in that region as the simultaneous break with the old socialist system, the rapid democratization, the opening-up of the markets and the rapid economic development. Instead they brought up to the topic of 'continuity and change' (Dittrich 1991) and a conception of emergent 'political capitalism', which is specific to Middle and Eastern Europe (Staniszkis 1991a; Stark 1994; Tatur 1998; Dittrich 2001).They argued that this type of capitalism aims at channelling state resources into private pockets, externalizing private costs on state and society, and opening up access to the state financial infrastructure.

Our and other researchers' experience shows the importance of horizontal networks of personal relations in economic and everyday lives. They are shaped by clear-cut norms of rights and obligations and a perceived moral boundary between those being included and excluded. The result of such a view is different codes of conduct (Schrader 1994) that are based on reciprocity and redistribution (Gouldner 1960; Polanyi 1979; Gregory 1997) within the networks, and impersonal profit seeking and even overreaching outside of them (Yurkova 2004).

In the past, the evaluation of the chances of economic transformation and development of Eastern Europe was largely shaped by the view of the

1 We are grateful to Volkswagen Foundation for the financing of this research.

2 The country projects were conducted by Tanja Chavdarova (Bulgaria), Jan Vlácil /Ivana Hollérova (Czech Republic) and Elena Kapustkina/Vadim Kapustkin (RF).

3 The terms 'traders, entrepreneurs etc.' used in this paper shall be used gender neutral and comprise both sexes. 
modernization and organizational restructuring of large enterprises/combines. We take another perspective. We assumed that the dynamics and the potential of successful economic development in a number of Eastern European societies can be found predominantly in small enterprises. From Western industrial economics we know that small and medium enterprises are considered to have a developmental potential because they are much more able to adapt to changing conditions than large enterprises. From political sociological perspective small and medium entrepreneurs build the core of the middle class, forming the backbone of civic society and providing stability in Western societies as well as a precondition for democratization processes in non-Western societies. From the perspective of economic sociology, firm owners risk their own capital and their private success is closely linked with the economic one.

The number of small and medium-sized enterprises in all Eastern and MiddleEuropean countries increased dramatically in recent years, despite of the fluctuation in that sector. One may view this as an indicator for economic dynamics. But we wanted to gain a more profound insight. Are the above mentioned 'assumptions' and ideas empirically sound or ideologically biased if we look at the three recently transforming societies? The core of our analysis aims at reconstructing the patterns of economic action, the resource combination during the foundation and the consolidation phase of the enterprises, their orientation towards networks or markets, and the socio-political and sociostructural consequences of their development.

\section{The necessary differentiation of the term "entrepreneur"}

Nearly any discussion on entrepreneurs borrows from Schumpeter. If we follow his 'Theorie der wirtschaftlichen Entwicklung' (1911), we can distinguish two basic types of entrepreneurs: the so-called 'Schumpeterian type' and the 'static host'.

\section{The Schumpeterian type of entrepreneur: the positive hypothesis of economic development}

Schumpeter's key hypothesis is that an entrepreneur is an economic innovator. $\mathrm{He}$ is less an inventor than a man of action ('Mann der Tat') in the economic sphere, an 'economic leader'. Not everybody, who is the owner of an enterprise or who is in a top level position in an enterprise, is an entrepreneur in this sense. A person only fulfils the key requirements of being an entrepreneur, when he opens up new economic opportunities, founds an enterprise, changes production processes, opens up new markets, does not hesitate to fight with other entrepreneurs for market shares, etc. According to Schumpeter entrepreneurship is a specific economic function, different to the inventor, the capital owner, the manager and the banker. To be entrepreneurial requires certain personal dispositions/skills. They comprise initiative, enthusiasm, readiness to decide and 
act but also certain mental limitations which make concentration on the immediate advantage possible. The intrinsic motivation, the will to build up a private economic empire and to be successful with it, in the eyes of Schumpeter have nothing in common with the motive of profit maximization (Schumpeter 1993: 172-174). Schumpeter contrasts this type with what he calls the 'static person' ('statischer Wirt').

\section{The post-socialist static host: the negative hypothesis of economic development}

The 'static person' lacks such a combination of leadership qualities, entrepreneurial success orientation, venture readiness, economic opportunity awareness and orientation towards societal progress as found in the entrepreneur. The key characteristic of the prototypical 'static person' is his behaviour as a 'labourer', offering his labour power in the form of selfemployment. He is no innovator, no man of action and is risk averse in his attitude.

The analytical version of the 'static person' is modelled not to be supportive of economic and social development in order to contrast him to the entrepreneur. The consequence of this is far-reaching, both for the economy as well as for economic theory. Empirically this would mean that there is no growth from small to medium-scale entrepreneurs, if 'static persons' dominate the terrain. On the contrary, if 'static persons' dominate the scene during transformation, one would have to expect retarding effects on the process due to the widespread threat of unemployment in post-socialist countries. Becoming self-employed would result from a safety strategy not from innovative action orientation or a motivation for general economic and social betterment. The static person is pushed into self-employment by the labour market forces, by threats of dismissal f.e. From such a perspective there is no such evolution of successful enterprises from small via medium to large ones as assumed by economic theory, but the economy consists of three rather independent sectors of small scale, mediumscale and large-scale enterprises. Or to put it another way, rather than developing into medium or large enterprises they have already been founded as such or transferred into such in the course of privatization in Eastern Europe.

A number of empirical facts can support the negative hypothesis of social and economic development. In the course of restructuring of the socialist into a market economy, many work places became redundant and many labourers were dismissed. Due to a very weak social security system those who were laid off had to find ways to make their living. One opportunity was the informal sector. And indeed, one can negatively correlate the number of small enterprises to the trade cycle because the informal sector provides a high a labour-absorption capacity in recessions or economic crises and provides a labour reserve for the formal economy during boom phases. Interestingly, this labour absorption 
capacity is not according to the size of the enterprises (number of employees), but according to their number in the economy. Another opportunity under these conditions is to become self-employed. As safety strategy intended, these selfemployed static persons don't act as entrepreneurs. Households and enterprises are not differentiated from each other, concerning both finance and employees. Household, family, relatives and close friends therefore provide a natural boundary for expansion of employees because this environment correlates with the sphere of trust (Schrader 2004). As a consequence of this lack of differentiation, the rationales of such small enterprises are less profit maximization and / or expansion of the enterprise and more household subsistence, and regeneration and generation of security, which cut across the motive of capitalist accumulation (Elwert/Evers/Wilkens 1983; Simon 1992). In such a socio-economic environment accumulation is orientated towards prestige, human capital formation among the kids, acquisition of living spaces, vehicles, large television sets, etc. Necessary financial means for investment are engendered by one's own social networks (family and friends). The highest 'capital', which simultaneously provides the highest impediment for the dynamics of one's own business, is the exclusive trust in one's own networks.

These types of small enterprises are not mobile, not flexible, because they are geographically and socially embedded in, and limited to the person's life-world and the local market. And of course they are non-innovative. Therefore, RonaTas concludes that the term 'small entrepreneur' does not reflect the real conditions, both due to the push factors that caused these businessmen to take the initiative and their perspectives on their own life-world. The static type lacks the entrepreneurial potential and perspective. It basically acts and reacts like an employee or labourer who wants to maintain the status quo as far as it guarantees his economic survival.

One may summarize the two types as hypotheses for empirical research as follows:

Table 1. Schumpeterian Type of Entrepreneur and 'Static Person'

\begin{tabular}{|l|l|l|}
\hline & $\begin{array}{l}\text { Hypothesis 1 (positive): } \\
\text { Type Schumpeterian } \\
\text { Entrepreneur }\end{array}$ & $\begin{array}{l}\text { Hypothesis 0 (negative) } \\
\text { Type,Static Person' }\end{array}$ \\
\hline Assumptions to & Entrepreneurial approach & Labour Market Approach \\
\hline size & $\begin{array}{l}\text { Size reflects a development } \\
\text { stage of an enterprise. There } \\
\text { is a continuum from small } \\
\text { via medium to large-scale } \\
\text { enterprises }\end{array}$ & $\begin{array}{l}\text { No such continuum exists, but } \\
\text { three independent, hardly related } \\
\text { segments }\end{array}$ \\
\hline
\end{tabular}




\begin{tabular}{|c|c|c|}
\hline motives of foundation & $\begin{array}{l}\text { Creativity, personal skills, } \\
\text { pull-factors }\end{array}$ & $\begin{array}{l}\text { Adaptation / reaction to external } \\
\text { development, push-factors }\end{array}$ \\
\hline relation to household & Separated / differentiated & Intermingled \\
\hline rationality criteria & $\begin{array}{l}\text { Expansion, profit } \\
\text { maximization }\end{array}$ & $\begin{array}{l}\text { Subsistence, reproduction of } \\
\text { security, perhaps also prestige } \\
\text { accumulation }\end{array}$ \\
\hline to mobility & Unlimited readiness & Restricted to life-world \\
\hline to resources & Formal / institutional & $\begin{array}{l}\text { informal (personal relations - } \\
\text { family and friends) }\end{array}$ \\
\hline $\begin{array}{l}\text { motivation of } \\
\text { accumulation }\end{array}$ & Economic, intrinsic & $\begin{array}{l}\text { social (prestige, human capital } \\
\text { and security for kids ) }\end{array}$ \\
\hline limitations & No & $\begin{array}{l}\text { Resources and employees from } \\
\text { household, family, friends' } \\
\text { networks }\end{array}$ \\
\hline future development & Growth & Survival, subsistence \\
\hline investment behaviour & $\begin{array}{l}\text { Extention (dynamic } \\
\text { expansion) }\end{array}$ & $\begin{array}{l}\text { Maintenance (simple } \\
\text { reproduction, statism) }\end{array}$ \\
\hline
\end{tabular}

Concerning our empirical research and under above mentioned auspices of entrepreneurship, we focused our investigations on (1) the biographical life situations of the entrepreneurs in the course of enterprise foundation, and (2) the support networks which reflect the individual biographies of the entrepreneurs as well as the historical situation.

\section{Quantitative results}

In the three countries considered we took 180 standardized interviews from six branches (services/ handicrafts related to housing construction; small-scale production/ handicrafts (excluding housing construction); catering trade; transport trade; and high-tech/highly qualified services). We investigated microenterprises that had already been established in the market for several years. The interview themes comprised questions concerning (a) information on the enterprises with regard to employees, capital and investment, support networks and supplier / customer relations; (b) information on the interviewee and / or founder of the enterprise; and (c) information on the economic framework, business success and planning. To allow for and analysis of the dynamics of development, various questions referred to the conditions in the setting-up period and the current situation of the enterprises.

$26 \%$ of all enterprises in our sample were individual foundations. In the Czech Republic and Russia, however, there were only very few individual founders, while in Bulgaria the number of single founders was over proportionately high. With regard to the type of co-founders and co-owners, we found that in the Czech Republic family members and relatives were over represented. 
With regard to employment structure our sample showed that in Russia $84 \%$ of the small enterprises employed paid, personally close people, ${ }^{4}$ in the Czech Republic 56\% and Bulgaria 43\% respectively. There are only slight variations between the starting and the present situation. The number of unpaid helpers, however, decreased in all three countries in the course of time, whereas in Bulgaria such people are still found in one fourth of the enterprises and therefore play a much more important role than in the other two countries. On the whole the small enterprises show a 7\% increase in full-time employees to now $66 \%$. Particularly in Bulgaria and Russia their number is high. The number of enterprises with part-time and irregular employment is relatively constant in all the three countries. Particularly very small enterprises have irregular employees. On average during the founding period $41 \%$, and nowadays $47 \%$ of the sample enterprises employ (socially insured) people. The highest negative deviation from the mean is in Russia ( $8 \%$ of the sample enterprises at both points in time).

About $25 \%$ of all enterprises didn't make investments in the past. Replacement investments are highly significantly found in Bulgaria, while amendment/expansion investments are almost the same in the three countries. The figures show that - due to financial limitations, refinancing possibilities or personal motives - only limited expansion takes place. Nevertheless, on average $53 \%$ of all enterprises experienced growth of turnover. The country comparison, however, shows highly significant differences. $70 \%$ of the Russian sample enterprises, but only $49 \%$ of the Czech and $34 \%$ of the Bulgarian enterprises reported such. $44 \%$ of the Bulgarian enterprises even stated that their turnover had decreased in the course of time.

\section{Support networks in country compression}

With reference to the extended capital terminology (Bourdieu, Coleman) we consider support networks an important source of generating resources. In addition to economic and capital, human capital support may also take the form of contacts, information, personal advice and protection/ security. These aspects are normally summarized under the term of 'social capital'. It is assumed that lack of capital of one of the three types can sometimes be substituted by one of the other capital types. Let us discuss these capital forms one after another with regard to our data.

In transforming economies small entrepreneurs engender their economic capital from their immediate life-world. During the foundation process own savings and loans from family and friends are taken as the main sources of finance, and they continue to be important, in addition to profits. Nevertheless, their importance decreases by one-third in the course of time, while suppliers and customers emerge as a new credit source. We interpret this in the following way. Business

4 To these belong family members, relatives, friends, well-known people and colleagues. 
relations based on contracts function insufficiently because legal action on breach of such a contract is not a feasible option and economic agents are morally weak. As institutional regulations only function in an insufficient way, small entrepreneurs rely on advance payments to secure themselves against risks of default. An additional important factor for such behaviour is that small entrepreneurs aim at binding suppliers and customers by credit relations to build up long-term business relations. In that way a network of credit relations between producers, suppliers and customers emerges. These networks of small entrepreneurs with their functional environment seem to be characteristic for transforming economies and often form a gray zone between formal and shadow economy.

Human capital among our group is high. This is particularly true for the Russian sample. Three quarters of the interviewed founders in Russia graduated from university, followed by $45 \%$ in Bulgaria and $32 \%$ in the Czech Republic. Also the percentage of founders who have graduated from a high school of applied science or technical college is high (Czech Republic 37\%, Russia 16\%, Bulgaria and 9\%). Looking at apprenticeships of founders, a technical one is found among half of the entrepreneurs, followed by social scientists and economists. However, among the Bulgarians and Russians it is common for the founders to have completed an education or training in an area which differs from their professional field. Thus, we assume that among such founders we find broken biographies in which career planning either did not take place or was not possible. A large number of founders were formerly employed in private enterprises, while only a small proportion with the exception of the Czech Republic (11\%) came from state or communal administration. In contrast to the Czech Republic and Bulgaria one-fifth of the Russian founders had already been self-employed before.

Our assumptions about economic exchange relations are supported by the data on social capital. Contacts and information in the business world of the entrepreneurs relate to the direct social environment. But family is not as important as in the case of financing. Friends provide more support?? Suppliers and customers are more important for the different components of social capital than banks, private business consultancies and the state, all of which play only a marginal role. These findings work against the endeavours of the World Bank, the European Union, but also governmental policy to support small and medium enterprises by credit programs, information and consultancy.

Western newspapers and scientific reports always refer to the unhealthy economic climate, corruption and Mafia-like structures in Middle and Eastern Europe, which provide an impediment for the market economy in general and economic agency in particular as if they represent the only means to gain security in high risk constellations of transforming societies. But forms of protection and security vary widely and play an important role for the 
entrepreneurs in our sample. They refer to both provision of security by private and institutional providers in the form of protection and insurance. Here the countries differ widely. In the Czech Republic insurance companies rank highest in importance $(28 \%)$. They are followed by family and relatives. On the third position we find friends. In Bulgaria family and relatives are most important $(50 \%)$, followed by friends $(20 \%)$, while insurance companies and the state play a marginal role only. With $11 \%$, private security structures are as important as customers. The situation in Russia is once again totally different. Highestranking are private security structures $(25 \%)$, followed by friends $(15 \%)$ and the state $(12 \%)$ and then family and relatives. Suppliers and customers rank as unimportant for security.

When we consider both, economic capital and social capital, we observe an obvious tendency in the Czech Republic. The importance of economic relations with family members and friends has decreased in the course of time, while the importance of personal-functional relations (suppliers and customers) has increased. In the two other countries social relations have continued to dominate the economic action of small entrepreneurs. In Bulgaria reference to immediate social environment is stronger than in the two other countries. In the Czech Republic, in turn, the role of banks as financiers is most important, while in Russia their role has strongly increased in the course of time. To put it another way, in Bulgaria the personalization of economic relations is particularly strong, which raises the question of trust / distrust and market institutions when we assume that system trust is low. In Bulgaria it seems to be even lower than in Russia. While Russian society suffered for some time from the shock of the 1998 crisis, as many observers underline, trust in the economy and in banks seems to have grown once again.

Unofficial payments are an integral part of economic activities in many countries but their extent varies greatly. The NGO Transparency International ranked Bulgaria on position 54 together with the Czech Republic and Brazil, and Russia on 86. Our questionnaire also considered informal payments to various institutions. Obviously such payments are made to state and communal administrations in the three countries, but have decreased in importance. The strongest decrease occurred in Russia (-12\%), whereas we have to admit that in the foundation period half of the enterprises mentioned them, compared to $38 \%$ today -still a very high ratio. Therefore Russia has the strongest deviation from the mean. For both points in time the Czech Republic reports comparatively low figures (19\% during foundation period, $12 \%$ for today) and therefore lies significantly under the mean. Informal payments to the police/militia are on a lower scale (mean 10\%) with the same ranking of the countries. Unofficial payments to security structures are rather unimportant in the Czech Republic (3\%) and Bulgaria, while they take place on a much higher level in Russia, however with decreasing tendency (from 17 to 9\%). Also suppliers and even 
banks obtain unofficial payments from small entrepreneurs. Again Russia ranks highest here, this time followed by the Czech Republic.

\section{Entrepreneurial qualities, motives for setting up enterprises}

We asked the small entrepreneurs to assess which qualities an entrepreneur needs to be successful (multiple selections) in his country. The qualities which we chose, concerned a personal-mental criteria, in analogy to those of Joseph Schumpeter or Max Weber (diligence, frugality, realizing chances) and to clientelistic relations that are usually ascribed to the economies of Eastern Europe of the type of 'political capitalism'. In the three countries the ranking of the entrepreneurial qualities is similar. The personal qualities/skills are generally considered to be more important than objective qualifications or clientelistic relations. With regard to relations to the local administration and socialeconomic organizations Russia deviates from the other two countries, considering such relations as much more important. Bulgarian small entrepreneurs, on the other hand, believe much more in risk-taking and in relations to colleagues from the branch.

We also gave our interview partners a number of potential motives for enterprise foundation which they had to consider with regard to importance and unimportance (multiple selections). Afterwards the research team grouped them in two categories: intrinsic motives (linked to the Schumpeterian type of entrepreneur) and instrumental motives (linked to static person). Considering the intrinsic motives, the data show that economic independence ranks highest in all three countries $(86 \%$ mean). The other intrinsic motives show strong variations between the three countries. For Bulgarian entrepreneurs the implementation of own ideas $(78 \%)$, proof of one's capability $(68 \%)$ and lack of decision-making possibilities in the form of employment (58\%) have important ranks. ${ }^{5}$ Also for a number of Russian entrepreneurs these are important, but on a lower level (average -10\%). For Russian (56\%) and Czech small entrepreneurs (52\%) the recognition of market chances is of particular importance. Among the instrumental motives the motive of building foundations for the future is very important in all three countries (Bulgaria 85\%, Russia 71\%, and the Czech Republic 79\%). For Bulgarian (84\%) and Russian entrepreneurs (69\%) more security also ranks important. Among other push factors Czech entrepreneurs strongly deviate negatively from the mean. Obviously they feel the threat of unemployment much less than Russians of Bulgarians.

5 Bulgarians consider the lack of decision competence in salaried employment an important reason for becoming independent entrepreneurs (53\%). 


\section{Economic frameworks, success, planning}

In our barometer of public opinion to the economic situation in the country, $73 \%$ of all Bulgarian respondents considered the situation as bad compared to $45 \%$ of the Russians and Czechs, who tended to an ambivalent position, or even to a positive assessment (13\% of the Czech). The majority of all entrepreneurs regard the state as a hindering factor for business. Here the Bulgarians rank ahead of the Russians and Czechs.

Quite interesting is that the assessment of the perspectives of the person's own enterprise differ immensely from the overall assessment of entrepreneurial activities. Here the optimistic and ambivalent assessments exceed the pessimistic ones. While the Czech and Bulgarian entrepreneurs are still a little bit hesitant, two thirds of the Russians are optimistic.

Assessing their own entrepreneurial activities, Russians and Czechs evaluate themselves as more successful. $40 \%$ of the Bulgarian entrepreneurs consider their own economic activity as less successful or even as a failure, compared to $32 \%$ of Czechs and only $28 \%$ Russians.

Highly significant are the differences with regard to planning. While more than $50 \%$ of the Russian entrepreneurs and even $68 \%$ of the Czech entrepreneurs have been planning for more than a year, only $24 \%$ of the Bulgarian entrepreneurs report this. Here those enterprises predominate which plan up to three months or do not plan at all.

\section{Qualitative research}

Let us now consider our qualitative findings. In each of the countries we took 30 interviews. Here we looked at the biographies of small entrepreneurs, the internal organization of their enterprises, cooperation and competition, relations to state institutions and the economic climate in the country. Many interviews contained long narrative parts that allowed for special insights.

Most Bulgarian entrepreneurs consider themselves honest small businessmen who aim at making a living with their families. Remarkable is that the respondents rarely consider themselves as entrepreneurs rather than professionals, businessmen and 'masters of their own destiny'. Typical is also the view that the profession "doesn't make one rich but the outcome should be sufficient to make a living". The entrepreneurial career is considered an increase of options, the chance to become one's own master, even if one was forced to do so as a result of labour market development.

Again and again the material shows a strong familial tendency. In such cases, where trust is necessary for an economic action - and trust is required for most economic transactions - our entrepreneurs rely on family and friends, although they are well aware of the negative side of such risks-minimizing orientation. 
Often such a decision is the result of a lack of resources, particularly in the foundation period where no capital is available for paying employees. But also later many of them prefer such security arrangements. Like the very negative attitudes towards state and bureaucracy showed, this result might be a cultural peculiarity that also corresponds to the evaluation of the economic climate as such.

The process of becoming independent often already starts in the state realm, which provided the major source of accumulation of resources. These resources are both cultural in the sense of qualification and social in the sense of social relations. Of course, this holds true for the more intellectual, rather than simple, scopes of function. In general, however, small entrepreneurs rely on personal trust, where they are also able to run their business without generalized norms.

Concerning the question of development of their enterprise the respondents predominantly referred to financial sources for investment. Here banks and governmental programs hardly play any role. The main source for investment is the immediate personal environment, the personal sphere of trust. Mutual dependence of small entrepreneurs seems to be quite normal. As the main impediment for the development of the enterprise, the respondents mentioned lack of purchasing power in the population, which was looked upon as causing expansion aims to mutate into aims of survival. Closely related to this is a strong orientation of economic activities to the family.

Important for the continuously addressed insecurity and the observed ongoing personalized relations is the redress on (organized) economic criminality. This phenomenon seems to be important for the assessment of the economic climate. That our respondents keep this system ongoing by bribing and corrupting has neither been realized nor picked out as a central theme in our interviews. The self-perception of honourable businessmen is not even disturbed by tax evasion, which is declared to be a constituent of the survival strategy against the greedy state and therefore legitimate.

For a number of Bulgarian respondents the orientation of economic action is mainly related to their own life experience, and this has not changed in the course of time. Regarding themselves as being confronted by obscure and uncontrollable social forces, personal trust in small straightforward networks, which provides the backing for one's small economic success, is very important.

A similar self-perception as in Bulgaria is found in the Czech Republic, where entrepreneurs rarely consider themselves as corrupt. In none of the interviews was the term 'profit' used. Czech small entrepreneurs prefer talking about 'the firm', which is considered to be a means of better living conditions. The decision for self employment is closely related to the wish of becoming "one's own master" or "one's own boss", although often push factors caused this first step. At the same time, many respondents mention that the profession should 
provide them pleasure. Their descriptions of entrepreneurial activity show a perception of a "capitalism of small people" as opposed to "capitalism" as such. This distinction directly corresponds with clear-cut conceptions of enemies (the state, large enterprises). Moral obligations to mutually support people from the same socio-economic background - even if they are competitors - are a result of this perception. "We" are supposed to jointly defend ourselves against the joint "enemy" - e.g. the state and large enterprises - and lead a morally sound way of life.

The starting capital was merely taken from the savings of the family and/or friends. Like in the other two countries these play an important role both for the start-up as well as for the period of consolidation. However, it is specific to the Czech sample that often no clear-cut distinction occurs between private and commercial spheres, contrary to Bulgaria and Russia. While particularly the Russians often provide self-perceptions which fit the image of entrepreneurs, conceptions of market economy and democracy like in text books of business administration and management, such images are more or less absent in the identities of Czech small entrepreneurs. Many respondents legitimize their conformity with the existing order by emphasizing that they aim less at 'profits' than self-realization. Entrepreneurship seems to be a "hobby" in the Czech case.

An orientation towards relatives and friends to cope with risks is quite strong, which may be related to the very low morality of payment of small entrepreneurs in the Czech Republic, which many respondents enunciate. Nevertheless, they perceive themselves as a group with a shared morality. This observation is a Czech peculiarity. Morality is a central theme in the interviews and is declared as orientating economic action. The 'economic traditionalism' in the sense of Marx Weber seems to be strongest in the Czech Republic, which constitutes an astonishing result for us. The environment, particularly the state and large enterprises constitute enemies, against which one has to defend oneself, and the best protection is "humanity" among small entrepreneurs.

In spite of the fact that the state belongs to the "'hostile environment", the overall economic situation is considered to be positive. Although state programs in support of small entrepreneurs exist, they seem to be rather unimportant for this group.

Almost all respondents consider taxes to be too high, and this legitimizes strategies of individual tax evasion. Such strategies do not cause moral contradictions, because they are necessary for survival. Interestingly, many Czech small entrepreneurs consider corruption of small administrators as an expression of capitalism with a human face, because such small people have to find ways for survival - like they do.

In Russia we find the strongest self-presentation in the sense of the Schumpeterian entrepreneur. Statements such as "I am a born entrepreneur" or 
"My blood contains the entrepreneurial spirit" are typical interview phrases. Such a self-perception often goes along with an orientation towards expansion, which we rarely found in Bulgaria or the Czech Republic. The Russian small entrepreneur considers himself as a "professional in his own mission" and aims at generating economic security for his activities. This does not exclude participation in informal networks, which seem to be characteristic for Russian everyday life and the economy as well.

The best way of coping with insecurity in a complex, contradictive reality seems to be to behave like an entrepreneur in the economic textbooks. For example, Russian entrepreneurs very often refer to problems with rented premises. Pure contract relations seem to be rather an exception in business life, so that rent contracts provide a source for personal dependency and limitations of economic activity. Owning one's business premises seems to be a solution for such a dependency, and many respondents mentioned this as one of their primary aims for the future.

The strong emphasis on trust and the human side of entrepreneurial activity is another characteristic of the Russian sample, where the respondents refer to friendship as the basis of economic activity. Friends seem to be much more important in the Russian sample than relatives, although very often the starting capital was collected from relatives.

Here we see a fundamental difference to particularly Czech entrepreneurs. While the latter have a traditional morality as the medium of orientation, in Russia we find a coexistence of humanity, sometimes morality and more abstract norms, mainly on the individual level. These norms are relevant in the configuration of the enterprise as well as in the relations with suppliers and customers, competitors and bureaucrats. The Russian motto seems to be: "With normal people one tries to find a reasonable agreement". This also serves as the legitimization for informal payments to the bureaucracy.

Respondents were much more open with regard to corruption and practices in the shadow economy than in the two other countries. They perceive them as implicitness in economic life. There was a general agreement on positive effects of tax reduction, but at the same time individual strategies developed - even transgressing legality - to decrease them further. For the respondents this is no contradiction to the reclaimed humanity and normative stabilization of economic action. These legal-cum-illegal practices provide a relative stable part of the context of economic action, which always has to be taken into consideration in interpretations.

Whereas the relation to the state can be characterized as ambivalent, although it is usually considered to belong to the 'hostile environment', the economic situation is predominantly perceived to be positive. We could not find an "usthem" polarity between the small people and the big business like in the Czech 
Republic. Like in the other two countries state-sponsored promotion programs do not play any role in the self-perception of Russian small entrepreneurs.

\section{Networks as structuring and amends of economic action in post- socialism}

Our research results allow us to make some cautious statements with regard to the morphology of the post-socialist order. The considered small enterprises and the owners represent a "world of small people", a communitarized life-word that can be characterized as follows: (1) it is based on informal networks which function (2) as a shield against the state, large enterprises and perhaps also globalization, and (3) as a socio-economic self-help mechanism, and such a functioning is also desired. Small enterprises and their owners in post-socialist countries can be understood only when we analyze them with regard to transformation aspects. Until now transformation has constituted their context of agency. Their start-up resources and their experiences predominantly originate from state socialism. They form the basis of their existence, they constitute security mechanisms against the state and they are forms of self-organization and self-preservation. ${ }^{6}$ Let us consider these three realms one after another with regard to hypotheses and research material:

\section{(1) Informal networks}

One of our central starting points was the assumption that small entrepreneurs in post-socialist societies may be considered supporters of transformation and expected to function as such because private entrepreneurs with personal liabilities have a higher potential for transformation. Compared to institutional owners, small entrepreneurs risk their own, often all of their property, while institutional owners only administer the property of others. Our empirical material suggests that we will have to drop this assumption. It was based on the idea of a relatively autonomous entity, the singled small enterprise. However, as we have shown this autonomy doesn't exist. Small enterprises are embedded in the context in various ways. This does not give them the freedom of acting as economic actors themselves within the setting of competitive markets. Market entry itself, but also consolidation is no pure economic matter, because small entrepreneurs are embedded in their life world. They don't apply for credit from banks or state promotion programs but raise the capital from family members, relatives and friends. In our empirical material there is no clear-cut distinction between private, business and public spheres; all of them are intermingled. Competition becomes only important for our respondents when it takes place within their own networks of socio-economic relations: as a form of strategic

6 Russian language refers to such networks as 'blat' relations (Ledeneva 1998). They belonged to the 'normality' of state socialist everyday lives and have continued ever since. 
cooperation. Verbal agreements, mutual liabilities, and deferred payments to suppliers and from customers structure competition in such a way that the small enterprises can survive. Even the state does not constitute a distinct sphere in so far that they try to incorporate bureaucrats into their networks to enlarge their social capital, even if bribery is required. Individually, our respondents do not perceive themselves as entrepreneurs in the Schumpeterian sense who support the market economy and technological progress; the other way around, they purse collective motives related to family, friends, and personally related suppliers and customers; they all share the same morality. They aim at survival and reproduction of themselves and their families, but not necessarily at an expansion of the enterprise. There is hardly an idea of legitimate entrepreneurship. How can we explain this? To answer this question we think that we have to change the analytical framework for analysis of small entrepreneurs.

We think that it makes more sense when we systematically investigate small entrepreneurs under the aspect of their mutual entanglement, as specific networks which seem to be more appropriate for agency in the particular historical and local setting than anonymous market relations. The advantage of such a perspective is to also take their non-economic strategies, which aim at both creating a planable environment as well as sustaining livelihoods, into consideration. Such a more comprehensive view is necessary to get a better understanding of such a group of entrepreneurs in the post-socialist setting (cf. Welter/Smallbone: 109). From the network-analytical perspective we can identify an action-theoretical pattern of small entrepreneurs which is characterized by "complex and reciprocal, more corporative than competitive and relatively stable relations between legally independent, economically, however mostly dependent enterprises" (Sydow 1992: 79). These networks have their specific shapes for the different branches and their particular conditions, but they also incorporate parts of the state apparatus as well as life-world contexts such as family, friends, etc. In so far they can be distinguished from networks of firms and their investigation in Western Europe during the past 20 years. The networks which we refer to cannot be considered as pure economic exchange nets of strategic cooperation, because these are not solely situated in the economic subsystem of society, but cut across other subsystems, the privatesocial one and the political one. The notion of political capitalism means that (until now) there has not been a clear-cut institutional differentiation of spheres although there are gradual differences between the three countries. Our impression is that small entrepreneurs, with their specific network-oriented patterns of action, preserve structural elements of state socialism. This is one more reason why the small businessmen cannot be compared to the Schumpeterian type of entrepreneurs. Not only on the macro level of political power, but particularly on the middle level of enterprises and the micro level of 
action the social embeddedness is crucial for an understanding of development and non-development of institutions and groups.

Our reading is that post-socialist transformation can be considered an interplay between an adaptation to inherited ways of action and new 'rules of the game' (Dittrich 2001; Dittrich/Fürstenberg/Schmidt 1997). We think in terms of path dependency. Our point of reference is real socialism which had never been fully controlled by the state but developed its own patents of solidarity and organization to get emancipated from state control. These late 'Soviet' patterns of solidarity and forms of organization have been named 'informal networks' and 'informal public' (Zdravomyslova/Voronkov 2002). These old patterns of social order were revived or were altered under the post socialist order, but they did not lose importance as was assumed by the system transfer approach - on the contrary, perhaps their importance even increased, since they provide an important tool for getting access to and securing one's position within the economy. In the Russian sample the university cohorts or military companions later appear as close friends with whom one founded the enterprise, obtained informal credit, advice or even protection. These friends found their position within the post-socialist society; they changed their positions as network agents but continued being part of one's personal networks. We can see such relations as a specific social capital which takes an important function in transformation periods and as belonging to the resource provision of particular agents. We empirically addressed this question with the extended notion of capital in the sense of Bourdieu (1979) and Coleman (1988). In addition to physical capital and human capital, it is particularly social capital if not even cultural capital which is related to economic success. As horizontal network capital it shows its importance on (a) the level of family and relatives, (b) the level of friendships which reach back to certain shared pasts at school, during the military service or at the university or felt solidarity based on ethnicity, common place of origin, etc. and (c) on the level of patronage capital, which provides the basis for building up relations with politically important persons. All the three forms of capital work together and shape the networks.

Informal networks are highly complex, multi-functional building blocks in these societies, and their functions are manifold: they provide possibilities for informal communication, discussion, exchange of information or system critique (cf. 'Russian Kitchen', 'Czech Pub' etc.), mutual support in coping with everyday problems by getting access to (state) resources for private use, handling of legal and illegal transactions. In the sense of the functionalist school of social anthropology these networks constitute a 'total social phenomenon' (Mauss 1990).

(2) Security function against the state in socialism and state and market in postsocialism 
Under conditions of state socialism these networks had an anti-state directedness, with which parts of the population reacted to the systemic repression and deficiency by building close networks within their life-worlds. These worked both functionally as well as dysfunctionally for the system, because they kept it running but at the same time raised "resentments against unjust exclusion" (Castells 2002).

These informal networks were media for coping with scarcity of goods, with which the deficits of a planned economy could be compensated legally or illegally within a largely non-monetary economy by means of reciprocity relations and barter. It is no secret to say that this was only partially successful. By means of 'credit slips' (Coleman), claims and liabilities in reciprocal relations such network relations were strengthened, kept alive and attained a long-term perspective (Kornai 2003).

These networks were based on the mechanism of exclusion of the excluded (Parkin 1971). This implied a dualistic world view, a double morality between 'us' and 'them' with a very strong morality of support within one's own networks and very low moral standards concerning others not included (Schrader 2004), whereas the state was perceived as an 'enemy' against which one had to protect oneself.

As the state was the all-dominating employer and allocator of chances, and everybody had access to certain state resources in his work place, the double morality legitimized the appropriation of state resources for private means. For the individual these resources were the input side in barter transactions, so to say representing the 'supply-side' in the second, informal economy.

The incorporation of parts of the state administration into one's own informal networks also belonged to the 'life in lie' (Havel). The central element of the closed informal networks was to get access to economic resources, information, protection and security. This resulted in an undermining of 'bureaucratic rule' of the state institutions.

What we have mentioned so far already shows parallels to the networks of agency of small entrepreneurs. The obvious continuation of existence - in what of the form - also in the post-socialism should therefore be an important recourse of social research on post-socialist societies. It is often argued that the transgression of 'deficits' (supply of commodities) and monetization of most exchange relations resulted in a starvation of these socialist elements (Chavdarova 1996; Suchodoyeva 1996), but our and other's research findings show, that this development is obviously more complex than assumed in a simple system transition approach with a starting point and a ending point. Of course, we do not deny that the aspect of appropriation of state resources is hardly important anymore for the present time since most state property has been redistributed (although it was particularly important during the 
privatization process). At the same time, however, other processes occur which seem to lead in the opposite direction - to an increase of importance of these building blocks of society. Worth mentioning are the abolition of various sociopolitical transfers, the privatisation of life risks and the increasing insecurity of life, which may strengthen the importance of networks that provide security for the individual by means of personal trust and mutual responsibility/reciprocity. In this sense it is not by chance that we can observe the renaissance of the topic of trust in transformation research.

From the perspective of institutional and network theories 'informal relations' and 'insider relationships' can be dealt with more concretely from the methodological point of view. Judith Sedartis (1997), for example, took Granovetter's (1977) conception of 'strong and weak ties' and Burt's model of network density to explain the development of commodity stock exchanges in Russia. She compared two alternative foundation processes of enterprises, spinoffs $^{7}$ and start-ups. ${ }^{8}$ She could show that the dense networks of spin-offs based on strong ties and shared pasts in biographies of employees are less competitive and less successful than start-ups. The latter were newly founded enterprises and had more head strong autonomy within more loosely structured networks, more far-reaching and less redundant contacts and higher efficiency. David Stark (1996) already showed quite early with his network approach for the analysis of property rights in Hungary, that not only path dependency is important for the development, but also continuity of formal and informal relations as important resources during the privatization process.

When the role of informal networks for the foundation and development of small enterprises in the post-socialist space is considered, the already discussed characteristics should not be overlooked, namely that, among other things, they constitute an organizational form for the mobilization and securing of access to state resources. We do not only refer to licensing and the possibility of getting cheap material resources but also to the control and decision competence of office bearers who once having been incorporated into such networks and can provide privileges to certain members using their own personal networks. With regard to the Russian Federation, Petrushina (1995) mentioned that for most entrepreneurs the decision for self-employment was a trial of courage. Successful were those who had access to efficient informal networks. This indicator can be generalized for all post-socialist societies. We do not talk about the level of nomenclature-foundations which occurred in the course of

7 Spin-offs are economic entities, which already had split from enterprises before reforms to make a living on their own. Their employees have known each other already from their former employment.

8 Start-ups are newly-found it enterprises which mainly function without support of the older organizations. The employees lack such a shared history as found among spin-offs. 
conversion of political power into economic resources in a number of economic core fields such as energy and armament or banks, but also to foundations of 'simple' citizens of state- and, later on, post-socialist societies, like our small entrepreneurs in this study.

To put it another way: when we talk about the support of family and friends during the foundation, in the rarest cases this support is limited to financial resources of the particular actor-centred networks. The acquisition of financial capital is related to chances of obtaining titles, certificates which once were acquired and are still important for the licensing of enterprises by the administration, as well as the human risk capital, this subjective disposition, which has an important influence on the foundation and development of an enterprise. A closer look at these resources shows that the particular resource combination of physical, human and social capital, which materialized in particular networks, predetermines success and failure of economic transactions to some degree. In various cases these resource combinations hint at an origin in state socialism. When we take such informal networks into consideration, the concept of 'political capitalism' in social science gets a more differentiated shape. Then also small entrepreneurs seem to be 'products of transformation'not only from the perspective of negation of the old system, but also as genetically "related" to state socialism. In the course of the development of an enterprise, the genetic component eventually fades out, while at the same time the display of entrepreneurial skills and competence provide means to burn the bridge to state socialism.

Networks play an important role not only in the foundation of small enterprises but also in their consolidation. While the state sphere as a source of material resources decreases in importance, the market can obviously not replace such informal networks. In present post-socialism, scarcity is no longer limited to the supplier of commodities, but takes other forms which are nonetheless important for economic sustainability. We refer to information on prices, cheap supply, reasonable and reliable credit, transaction partners, etc. and to control- and decision competence in the form of security in agency and planning. Confronted by an underdevelopment of formal and informal institutions, a hardly transparent let alone controllable environment, and a high emphasis on personal trust as individual motive for decision-making, informal networks play a decisive role as a mechanism of access to these new 'scarcities' just described and for engendering security in a turbulent environment.

As a consequence of this all encompassing character of privatisation as well as the massive limitation of state finance, the phenomenon of 'quasi privatization' of state control from the side of the particular office bearers (customs officers, tax officers, police, regional administrators, distributors of state demand, etc.) seems to have become a post-socialist matter of course. For the conversion of these resources into economic capital in the sense of the supply of their 
'curators', these informal networks are indispensable. Our interview partners often said that "these officials do not do deals with strangers", which means that an intermediary role in informal relations is important for the securing of such a supply. To put it another way, it is an interest of such administrators to interlock to such networks and take advantage from such 'blat' relations, when they do not want to risk the denouncement of corruption. This shows that such informal networks constitute an important part of the morphology of post-socialist societies. These forms of social organizations are based on certain conditions of the societal systems, which give the 'old' networks new functions. How this can be assessed with regard to functionality and dysfunctionality is an empirical question.

We argue that participation in / exclusion from such social networks is a decisive factor for the social position of individuals. This held true for state socialism. Such networks usually have a personal character which is based on different resources and loyalty structures. During the foundation period of small enterprises, these networks were small and related to the immediate environment: family, friends who could mobilize resources. The networks' participants knew each other, depended upon each other and relied upon their agreements. Trust, reciprocity and reputation, which is built up by a long-term cooperation, are always important under conditions when it would be very expensive to change one's partner, but a vertical integration of production factors is neither demanded nor possible. Trust and reciprocity are crucial elements of economic action and provide security against the unpredictable developments in the 'large' economy. To be part of a network decreases transaction costs. A large part of these costs relates to acquisition and handling of information, and favours network participants who can better interpret signals than outsiders. Furthermore, trust decreases the transaction costs of monitoring and contracts. Personal networks, which are based on trust, can be considered to constitute moral economies, due to the disciplining functions for members. Oliver Williamson (1975) demonstrates, in his assaults on economic coordination, that under conditions of uncertainty market steering can become sub-functional compared to hierarchy and particularly networks. The networks that we described can be considered highly functional under post-socialist conditions of insecurity, and therefore it is inappropriate to consider them as 'inefficient socialist relicts' which hinder the process of catching-up modernization.

Even in such cases where economic activities are not based on 'old' networks and agents have to rely on their immediate environment (family, relatives, friends) these networks immediately begin to grow beyond that close sphere of relations, to make business more planable and keep transaction costs low. Second-order networks so to say emerge, the 'nodes' of which constitute the single enterprises, which regulate the relations to their 'relevant environment' 
(Crozier/Friedberg) such as customers and suppliers and to the state institutions, mainly on an informal basis.

The result for state institutions is that they are undermined by informal, personal relations between bureaucrats and citizens. They constitute 'facades' behind which administrators pursue their personal interest. Once such a situation has been established, a 'lock-in' effect occurs. Then the de-legitimized state organs need informal networks to cope with the citizens and these informal relations provide the basis for a rather calculable environment for them. In this way our entrepreneurs do not become a cue ball of the arbitrariness of administrators, but instead rely on their backing once they have locked in. Typical examples of such potential agencies of arbitrariness are hygiene departments, sanitation and fire protection departments, market administration, police/militia, tax offices and courts. In the same way, close, personalized relations to suppliers and customers generate security. From the functional perspective such strong ties, both to business partners and administrators, provide a substitute for contracts and standardized procedures of formal institutions/bureaucrats. Informal negotiations on a 'human' basis constitute the main steering mechanism in such an environment. Reciprocal obligations emerge, coordinate the exchange and provide extra security.

(3) Socio-economic self-help

The fundament for these reciprocal obligations is the consciousness of community in the Weberian sense. Our investigated small entrepreneurs show a subjective sense of solidarity, which astonishingly includes both their competitors as well as low-ranking bureaucrats. The necessary setting apart from a third group in a process of identity formation, which we described, seems necessary for the process of communitization (Vergesellschaftung). This process is described when the entrepreneurs' talk about large enterprises, large competitors and high bureaucrats and politicians and it is assumed that any of them would sell their own grandmother for the sake of making personal profits. In this sense the informal networking of small enterprises is also an expression against radical individualism. In these networks agents seem to build their community around the values 'god, family, nation and justice'.

On one the hand networks constitute morphological structures. However, these are not inflexible, durable patterns, since they change with actions and interactions of network agents. This means, that on the other hand networks have an interactional dimension (Hessinger 2001: 35f.). The relations to family members and friends, suppliers and customers, competitors and low bureaucrats, which again and again have been addressed by our informants, can be integrated into our interpretation of networks as patterns of activation, as the interactional, dynamic side. Such patterns of activation are not arbitrary and they depend on the space-time conditions in the particular local setting. In so far they are closely related to the morphological structure. In other words, networks cannot be 
discretionarily extended or changed, although the metaphorical use of the term networking seems to imply that this would be the case. Without empirical proof by a long-term investigation, the fact that the considered enterprises do not change into medium-term or even large enterprises leas us to the conclusion that their embeddedness in such small entrepreneurial networks means two things at the same time: stability and restraint for development. This assessment is contrary to older investigations (Suchodoyeva 1996; Chavdarova 1996) which concluded that, in the course of the development of small enterprises, the change from face-to-face relations to faceless ones with the chance to enter into a business world where money and contracts are the dominating media of exchange goes along with an expansion of these enterprises. In our own data we do not find support for such an assumption. While the moral scripts of small enterprises perceive large enterprises and banks as negative and the world of the small people as positive and desirable, small entrepreneurs cannot start a development where the banker becomes 'the friend of the entrepreneur' (Schumpeter). This implies a self-limitation of resource input to the immediate neighbourhood and to only those transactions which are indirectly backed by loyalty relations. From the perspective of consolidation of business activities and an adaptation to continuous change, such networks indeed engender stability. Our initial hypothesis, however, also aimed at the idea of an evolution from a small to medium and large enterprise. According to Schumpeter development means new resource combinations from new sources and spheres or a change of given organizational patterns so that the "entire way of economic circulation' (Schumpeter 1993: 98) will change. In our investigation, however, we only see the development of protection (Schumpeter 1975: 145) in the form of networking: familism and personal trust relations, mutual debts, patronage, corruption, insurance, extortion etc. Worth mentioning among this group of entrepreneurs is particularly that money does indeed provide an important medium of exchange; however, this is not sufficient for success and economic transactions, and therefore has to be supplemented by liabilities, mutual dependency relations, loyalty bonds and morality. Contracts in the business of small entrepreneurs only have a subordinate function as a means of protection. To put it another way, the business networks described here do not develop in the direction of a market model which is dominated by markets and hierarchies as steering mechanisms.

Our results support such research claiming that more complex taxonomies of economic forms of coordination have to be taken as the basis for the analysis of economy and society (Boyer/Hollingworth 1997; Sydow 1992; Hessinger 2001).

\section{References}

Bourdieu, P. (1979): Les trois états du capital culturel. Actes de la Recherche en Sciences Sociales 30, 3-5. 
Burt, R.S. (1992): Structural Holes. The Social Structure of Competition. Cambridge, MA.

Castells, M. (2002): Die Macht der Identität. Teil 2 der Trilogie: Das Informationszeitalter. Opladen.

Chavdarova, T. (1996): Informelle Netzwerkhilfe und Strategien der wirtschaftlichen Aktivitäten in Bulgarien. 237-246 in: Glatzer W. Lebensverhältnisse in Osteuropa. Prekäre Entwicklungen und neue Konturen., Frankfurt, New York.

Coase, R.H. (1988): The Firm, the Market and the Law. Chicago.

Coleman, J. (1988): Social Capital in the Creation of Human Capital. American Journal of Sociology 94 95-120.

Dittrich, E. (Hg). (2001): Wandel, Wende, Wiederkehr. Transformationen - Gesellschaftlicher Wandel. Würzburg.

Dittrich, Eckhard, Friedrich Fürstenberg, and Gert Schmidt (Hg.). 1997. Kontinuität im Wandel. München.

Dittrich, E./Heiko S./Christo S. (2006): Von Wirten und anderen Entrepreneuren. Kleinunternehmen in Bulgarien, Tschechien und der Russischen Föderation. Münster.

Elwert, G./Hans-Dieter E./Werner W. (1983): Die Suche nach Sicherheit. Kombinierte Produktionsformen im sogenannten informellen Sektor. Zeitschrift für Soziologie 12, 281-296.

Gouldner, A. (1960): The Norm of Reciprocity. A Preliminary Statement. American Social Review 25, 161-178.

Granovetter, M. (1977): "The Strength of Weak Ties." in: Social Networks. A Developing Paradigm,New York.

Gregory, C.A. (1997): Exchange and Reciprocity. in: Companion Encyclopedia of Anthropology. Humanity, Culture and Social Life, London.

Hessinger, P. (2001): Vernetzte Wirtschaft und ökonomische Entwicklung. Wiesbaden.

Kollmorgen, R./Heiko S. (2003): Postsozialistische Transformationen: Gesellschaft, Wirtschaft, Kultur. Theoretische Perspektiven und empirische Befunde. Würzburg.

Kornai, J. (2003): Honesty and Trust in the Light of the Post-Socialist Transition. http://post.economics.harvard.edu/faculty(kornai/papers/beszelo_English.pdf (Zugang Juni 2003).

Ledeneva, A.V. (1998): Russia's Economy of Favors: Blat, Networking and Informal Exchange. Cambridge.

Mauss, M. (1990): Die Gabe. Form und Funktion des Austauschs archaischer Gesellschaften (repr.). Frankfurt/M.

Parkin, F. (1971): Class Analysis and the Political Order. London.

Petrushina, E. (1995): Russia's Young Wolves Grow Hungry for Power. 07, 14.

Polanyi, K. (1979): Ökonomie und Gesellschaft. Frankfurt/Main.

Rona-Tas, A. (2001): Legacies, Institutions and Markets. Small Entrepreneurs in Hungary, Slovakia and the Czech Republic. 176-194 in: Successful Transitions. Political Factors of Socio-Economic Progress in Post-socialist Countries, Baden-Baden. 
Schrader, H. (2004): Spheres of Trust, Social Capital and Transformation in Russia. 79-102 in: Trust and Social Transformation. Theoretical approaches and empirical findings from Russia, Münster.

Schumpeter, J. (1993): Theorie der wirtschaftlichen Entwicklung. Eine Untersuchung über Unternehmensgewinn, Kapital, Kredit, Zins und Konjunkturzyklus. Berlin.

Schumpeter, J.(1975): Kapitalismus, Sozialismus und Demokratie. München.

Sedatis, J. (1997): Newtork Dynamics of New Firm Foundation: Developing Russian Commodity Markets. in: Restructuring Networks in Post-Socialism. Oxford.

Simon, H.A. (1992): Economics, Bounded Rationality and the Cognitive Revolution. Aldershot.

Staniszkis, J. (1991a): Dilemmata der Demokratie in Osteuropa. in: Demokratischer Umbruch in Osteuropa, edited by Rainer Deppe. Frankfurt/M.

Staniszkis, J. (1991b): The Dynamics of Breakthrough in Eastern Europe. The Polish Experience.

Staniszkis, J. (1998): Postkommunismus. Versuch einer soziologischen Analyse. 112, 375394.

Stark, D. (1992): The Great Transformation? Social Change in Eastern Europe. Contemporary Sociology 21, 299-304.

Stark, D. (1992b): Path-Dependence and Privatization Strategies in East Central Europe. East European Politics and Society 6, 17-51.

Stark, D. (1994): Nicht nach Design: Rekombinierte Eigentum im osteuropäischen Kapitalismus. 94, 127-142.

Stark, D. (1996): Networks of Assets, Chains of Debt: Recombinant Property in Hungary. in: Corporate Governance in Central Europe and Russia, Vol. 2, Budapest.

Suchodojeva, L.F. (1996): Der Wandel der Unternehmenskultur in Rußland durch das Entstehen kleiner Unternehmen. 133-140 in: Wandel von Unternehmenskultur in Ostdeutschland und Osteuropa. II. Chemnitzer Ostforum, München/Mering.

Sydow, J. (1992): Strategische Netzwerke. Wiesbaden.

Tatur, M. (1998): Ökonomische Transformation, Staat und moralische Ressourcen in postsozialistischen Gesellschaften. 112, 334-374.

Welter, F./David S. (2003): Entrepreneurship and Enterprise Strategies in Transiton Economies: An Institutional Perspective. 95-113 in: Small Firms and Economic Development in Developed Transition Economies: A Reader, Aldershot.

Williamson, O.E. (1975): Markets and Hierarchies. New York.

Yurkova, I. (2004): Der Alltag der Transformation. Kleinunternehmerinnen in Usbekistan. Bielefeld. transcript.

Zdravomyslova, E./Viktor V. (2002): The Informal Public and Soviet Society: Double Morality at Work. Social Research 69, 49-69. 